\title{
ERNYES MIHÁLY
}

\section{Nyomozás a polgári kor hajnalán}

\begin{abstract}
A Pécs-Baranyában történt emberéletet kioltó büncselekmények, néhány jogtudós/jogi szakíró munkái és természetesen hatályos jogi normák alapulvételével törekszem bemutatni a címben megfogalmazott témakört. Az ugyancsak a címben jelölt időszakon a kiegyezés utáni megközelítőleg évtizednyi időtartamot értem, jelezve, hogy néhány gondolat erejéig visszanyúlok az októberi diplomáig. Nem kívánok részleteiben, mélységeiben foglalkozni elméleti kérdésekkel, azokat csupán a bemutatáshoz szükséges mértékig érintem.
\end{abstract}

\section{Levéltári források}

A Magyar Nemzeti Levéltár Baranya Megyei Levéltárában (MNLBaML) viszonylagos bőségben lelhető fel a kiegyezés utáni időszak Pécs-Baranya bünfenyítő gyakorlatába betekintést engedő törvényszéki iratanyag. Többnyire a bírósági ítéletek ôrzik a bünesetekre vonatkozó adatokat, ennek következtében - az ügyiratok hiányosságai miatt - számos információ rejtve marad az érdeklődő elött. Ez tetten érhető a büntetőperek előkészítő szakaszában végzett nyomozások és vizsgálatok esetében is. Az emberi élet kioltásával végződő büntények aktái azonban így is alkalmasak bizonyos körülmények bemutatására, ismeretek szerzésére, gyakorlati kérdések, részterületek érintésére.

Pécs város visszaállított törvényszék 1869 és 1871 közötti és a Pécsi Királyi Törvényszék ${ }^{1} 1872$ és 1876 közötti, átnézett irataiból huszonegy olyan akta található, amelyekben az elkövetett büncselekményekkel emberélet kioltására került sor. A vádlevelekben tett indítványok szerint három eset rablógyilkosság volt, öt rokongyilkosság, négy gyermekgyilkosság, illetve gyermekölés, hét gyilkosság, egy vétkes emberölés, egy verekedés közti em-

\footnotetext{
1 Az októberi diploma kiadása után 1871 végéig müködött Pécs (szabad királyi) város (visszaállított) törvényszéke (bíró, tanácsnokok, jegyzö, tiszti ügyész) és Baranya Megye Fenyítő Törvényszéke (alispán, táblabírák, szolgabíró, esküdt, jegyző, tiszti ügyész). 1872. január 1-jétől, az 1871:XXXI. tc. rendelkezése alapján, a 39. számú elsőfolyamodású törvényszék a Pécsi Királyi Törvényszék lett, ahová a megszünő városi és a megyei törvényszék áttette a folyamatban lévő ügyeket. A levéltár az addigi városi iratokat külön kezeli, az időhatáron átnyúló akták a Pécsi Királyi Törvényszék iratállományába kerültek.
} 
berölés. Három ügyirat teljes anyagot tartalmaz, három majdnem teljes, a többi akta csak bírói ítéletekből áll. Ismeretlen tettes ellen indult kilenc eljárás, ezek folyamán felderítették az elkövetőket egy napon belül két; két napon belül három; három napon belül egy; tizenegy napon belül egy; tizenöt napon belül két esetben. Tizennyolc ügyben huszonhatan voltak letartóztatásban, illetve vizsgálati fogságban. ${ }^{2}$ Az elsőfolyamodású bíróság elé került egy hónapon belül két; két hónap után négy; hat hónap elteltével kilenc; egy év múlva három; tizennyolc hónap után két; öt évvel később egy ügy.

A közvádló ${ }^{3}$ minden gyilkosság ${ }^{4}$ elkövetőjére halálbüntetés kiszabását kérte. Az eljáró törvényszék négy ügyben négy embert ítélt halálra. ${ }^{5}$ Öt alkalommal került sor, többnyire a felsőbb bíróságok által, pótnyomozás, illetve pótvizsgálat elrendelésére.

\section{Szakirodalom}

A korabeli szakirodalom négy kiemelkedő alakjának munkái nyújtottak segítséget e tanulmány elkészítéséhez.

Rendkívüli jelentőséggel bírt Pauler Tivadar (1816-1886) jogtudós, politikus három kiadást megélt, először 1864-ben megjelent, Büntetőjogtan címü kétkötetes könyve. A szerző e müvét a Birodalmi Törvénylap által hordozott német elméletre, az ausztriai büntetőtörvényre, az ausztriai büntető perrend-

\footnotetext{
2 A letartóztatás (elöleges/előzetes letartóztatás) és a vizsgálati fogság megkülönböztetéséről lásd Kassay Adolf: Magyar büntető törvények s bünvádi eljárás az országbírói értekezlet szabályai szerint. Sierer Henrik Könyvnyomdája, Pozsony, 1862, 87-88. o.; Pauler Tivadar: Büntetőjogtan. Harmadik kiadás. Pfeifer Ferdinánd, Pest, 1872-1873, II. kötet 392-396. o.; Székács Ferenc: A magyar büntetőeljárás kézikönyve. Franklin Társulat, Budapest, 1881, 25-30. o.; Sárga könyv. Ideiglenes eljárási szabályzat. 20-29., 45-46. §. A felsorolt szerzők kellően utalnak az 1872 előtti szabályozásokra és az Ideiglenes eljárási szabályzat rendelkezéseire is.

3 Közvádló 1872-ig, aki felperesként a fenyítő törvényszéki ügyet a bíró elé terjesztette. Rendszerint az ítélő törvényszék tiszti (fö/al) ügyésze. 1872. január 1-jétől a királyi ügyész/alügyész. 1871:XXXIII. tc. 17. $\S$

4 Gyilkosságot követ el, aki embertársát megfontolt szándékkal, meggondolt eltökéltséggel, életétől jogellenesen megfosztja. Szántszándékos gyilkosok , a mely emberek, eltökélt szándékkal követnek el emberölést”. 1486:LI. tc. Szándékos és elöre eltökélt emberölést követnek el „, a mely emberek, eltökélt szándékkal követnek el emberölést”. 1492:LXXXII. tc. Hármaskönyv, II. 44., 46., 54.; Pauler Tivadar: i. m. 122. o. „Törvényeink szerint az ki embertársát megfontolt szándékkal, meggondolt eltökéltséggel, életétöl jogellenesen megfosztja, gyilkosság büntettét követi el. Minösitett a gyilkosság, ha a rokonon, mint jelen esetben, a legelvetemültebb gonoszság kifolyásaként édesatyján hajtatik végre." Pécsi Királyi Törvényszék 1875/V.21. büntető irata, 1650.bünt./1875. sz. ítélet indokolása.

5 A végigkövethető ügyekben részben a Kúria enyhébb ítéletet hozott, részben az uralkodó kegyelmet gyakorolt.
} 
tartásra, a hatályos magyar törvényekre és miniszteri rendeletekre, az Ideiglenes Törvénykezési Szabályokra, a magyar büntetőbírói gyakorlatra, az 1843. évi magyar büntető törvényjavaslatra alapozta és kiegészítette az Ideiglenes eljárási szabályzat rendelkezéseivel. Alkotása olyan sikeressé vált, hogy alkalmazták tananyagként, jogszabályként, magyarázó jegyzetként, és a bírói gyakorlat is elfogadta. ${ }^{6}$

Az érdemes munkák között szerepeltetendő az 1836-ban Budán kiadott, Szlemenics Pál (1783-1856) által készített Magyar fenyitö törvény címü öszszefoglalás, amely sokáig az egyetlen magyar nyelvü kézikönyv volt a témakörben. Szlemenics a Magyar Tudományos Akadémia első jogász tagjaként egyik megteremtője volt a magyar nyelvü jogtudománynak. E müvének javított és bővített ötödik kiadása Pesten látott napvilágot 1872-ben, halála után tizenhat évvel. Utóbbi szerkesztője bedolgozta az országbírói szabályelveket, az első kiadás utáni törvényeket, a kibocsátott uralkodói és miniszteri rendeleteket, illetve az általuk bekövetkezett módosulásokat, az 1843. évi büntető törvényjavaslatot, valamint az Ideiglenes eljárási szabályzatot.?

1862-ben, Pozsonyban hagyta el a nyomdát Kassay Adolf (1828-1903) ügyvéd, jogi szakíró Magyar büntetö törvények s bünvádi eljárás az országbírói értekezlet szabályai szerint címü müve. E könyv 132 oldal terjedelemben foglalja össze a büntető anyagi jogi és a büntető alaki jogi rendelkezéseket.

1881-ben szintén könyv formájában jelent meg Székács Ferenc (1844-1901) bíró, jogi szakíró A magyar büntetőeljárás kézikönyve címü műve, amelyben a szerző többes cél elérését tüzte ki. Részben gyakorlati segítséget nyújtani az ifjú jogászoknak, részben anyagot szolgáltatni a büntetöeljárás kodifikációjához. Úgy gondolta, a kiadást megelőző tíz év a büntetőítélkezés terén elégséges tapasztalatot halmozott fel, ezek közreadása, a törvénykezés késedelmessége miatt, hiánypótló. Erőteljesen utalt arra, hogy az Ideiglenes eljárási szabályzat komoly megállapodottságra vezette a gyakorlatot.

\section{Jogszabályok}

A kiegyezéssel a polgári államszervezet kiépítésének lehetősége mellett megnyílt az út a magyar jog, így a magyar büntetőjog fejlődést célzó változásai

6 Pauler Tivadar: Büntetőjogtan. Első kiadás. Pfeifer Ferdinánd, Pest, 1864

7 Szlemenics Pál: Magyar Fenyítő Törvénykönyve. Ötödik, bővített kiadás. Heckenast Gusztáv, Pest, 1872 
elött is. E körben a mérföldköveket jelentő jogszabályok megalkotása elkezdődött ugyan a jelölt történelmi eseménnyel, a feladat nagysága s ebből fakadóan a végrehajtás azonban időt is követelt magának. Kezdetben vissza kellett térni az 1848 előtti szabályokhoz és kodifikációs kísérletekhez, mígnem hatályba léptek a büntető anyagi és büntetőeljárási szabályokról szóló törvények. A XIX. század utolsó harmada számos jelentős döntés születésének és kiteljesedésének adott teret fontos jogszabályok általi megjelenítéssel, illetve azok alkalmazásával. A gazdasági fejlődést közben beárnyékolta a bécsi tőzsdekrachhal 1873 tavaszán kezdődő válság, amely a társadalom minden területén éreztette hatását.

A Ferenc József által 1860-ban kiadott októberi diploma nyomán Magyarországon visszaállt az 1848 előtti intézményrendszer. A felszínre kerülő jogalkalmazási nehézségek leküzdését célozva, október 2-án az uralkodó összehívta az 1861. január 23-tól március 4-ig ülésező Országbírói Értekezletet. A tizennyolc ülés folyományaképp megszületett az Ideiglenes Törvénykezési Szabályok, amelyet a július 23-án tartott kúriai ülés, eltérő alkotmányos rendelkezésig, zsinórmértékül fogadott el. ${ }^{8}$ Ezzel befejeződött a visszatérés a kodifikálatlan régi magyar büntetőjoghoz, alapvetően a Hármaskönyvhöz, amelyet érintően két jelentős változás történt. Nevezetesen annak kimondása, hogy nemes és nem nemes között többé különbség nem lehet, továbbá testi büntetés bűntetteknél egyáltalán nem alkalmazható. ${ }^{9}$

A bünvádi eljárás a szokásjogon alapult, és a legmélyebb kútfö, amelyből szabályaira vonatkozóan meríteni lehetett, a törvénykezési gyakorlat volt $\mathrm{s}$ néhány évtizedig az is maradt. ${ }^{10}$

A modern állam jogrendszerének és igazságszolgáltatásának a megteremtése szempontjából alapvető jelentőségű volt a bírói hatalom gyakorlásáról szóló 1869 . évi IV. törvénycikk ${ }^{11}$, amely államosította a bíráskodást, $\mathrm{s}$ elválasztotta az igazságszolgáltatást és a közigazgatást. Kimondta, hogy ,, az igazságszolgáltatás a közigazgatástól elkülönittetik” és e hatóságok ,, egymás hatáskörébe nem avatkozhatnak”. A közigazgatási jogszabályok közül nagy jelentőséggel bírt a köztörvényhatóságok rendezéséről szóló 1870. évi XLII. törvénycikk, annak ellenére hogy Buda és Pest beligazgatási kérdéseire nem vonatkozott.

8 Ráth György: Az Országbírói Értekezlet a törvénykezés tárgyában. Első kötet. Landerer és Heckenast,

11 Kihirdetve 1869. július 15-én; 2000 óta a bíróságok napja. 
Az 1871. évi XXXI. törvénycikk az elsőfolyamodású bíróságok rendezéséről szólt, alapvetően szervezeti, illetékességi és hatásköri rendelkezéseket tartalmaz.

A királyi ügyészségről szólt az 1871. évi XXXIII. törvénycikk ${ }^{12}$, amelynek első szakasza szerint „,Az igazságszolgáltatás körül az állam közérdekeit a jelen törvény által meghatározott ügyekben a királyi ügyészség képvise$l i$ ”. A bíróságoktól független szervezet az igazságügy-miniszter közvetlen alárendeltségében müködött, tagjait pályázat után, a király nevezte ki.

1874-től az ország bíróságainál és hatóságainál ügyvédként olyan jogászok járhattak el, akik megfeleltek az ügyvédi rendtartás tárgyában hozott 1874. évi XXXIV. törvénycikk rendelkezéseinek.

A büntetőjog területén fontos rendelkezéseket hozott az 1871. évi LII. törvénycikk ${ }^{13}$ a büntetötörvényekröl és némely intézkedésekröl. E szerint a „testi fenyíték” semmilyen büntetésként sem alkalmazható, megszünik a bilincs büntetésként való használata, továbbá ,eltöröltetik a vérdijj”. ${ }^{14}$

A büntetőeljárást az előzőeken túl az 1872-ben miniszteri rendelettel kiadott Ideiglenes eljárási szabályzat szabályozta. ${ }^{15}$

Megjegyzendő, hogy 1854-től az osztrák büntető perrendtartás lépett hatályba, amelynek befolyása a régi magyar joghoz történő visszatérés után is érzékelhető volt.

\footnotetext{
12 Kihirdetve 1871. június 10-én; 1991 óta az ügyészség napja. A bíróságokról és az ügyészségről szóló úgynevezett szervezeti törvények 1872. január 1-jén léptek hatályba.

13 Bécs, 1871. december 21.

14 Baranya Megye Fenyítő Törvényszéke 1871. november 13-án vádlottat vérdíj megfizetésére is marasztalta. A Pesti Királyi Ítélőtábla 1872. február 22-én az ítéletet helybenhagyta. A Kúria 1872. április 10-én hozott döntésében kimondta, hogy „A Pesti Ítélőtábla ítélete az 1871. évi LII. t.c. 7-dik §-a által időközben eltörölt vérdíj elhagyásával, többiben a felhívott indokoknál fogva helyben hagyatik". Kettős változást tükröz. Átvett ügy a megyei törvényszéktől a királyi törvényszékhez került, az idöközben eltörölt vérdíjat elhagyták. Igaz, a vérdíj eltörlését a királyi ítélőtábla nem észrevételezte. MNLBaML 1872/V.344.

15 Előzményét Bittó István igazságügy-miniszter felkérésére a Csemegi Károly által elkészített A királyi törvényszékek illetékességéhez tartozó bünvádi eljárás ideiglenes szabályozásáról szóló törvényjavaslat jelentette. A tervezetet a miniszter 1872. március 6-án a képviselőházhoz benyújtotta, azonban elfogadására nem került sor, mivel az országgyülés feloszlott. Az anyag miniszteri köriratként - Finkey Ferenc (Finkey Ferenc: A magyar büntetőperjogi tudomány háromszázados fejlődéstörténete 16191914. Sárospatak, 1948. A jogászok a Kultúráért Alapítvány kiadmánya, 2000) szerint Pauler Tivadar által kiadva - szolgált útmutatóként huszonnyolc éven át, a büntető perrendtartásról szóló törvény megszületéséig. Ez a 122 paragrafusból álló negyvenhét oldalas Ideiglenes eljárási szabályzat (az ideiglenes bünvádi eljárásról szóló törvényjavaslat) a kiadvány borítójának színe után Sárga könyv néven vált ismertté, s mint szokásjogi forrás lett eljárási kódexszé.
} 


\section{Előkészítő szakasz}

A büntető felelősségre vonás folyamának egyes elnevezései, illetve azok változásai a szabályozások következtében némiképp eltérők. Az 1869-es év a bíróságok államosításával, az 1872-es esztendő, az elsőfolyamodású bíróságok rendezéséről szóló törvénnyel, majd az Ideiglenes eljárási szabályzattal a tartalmi változások mellett határvonalat is húzott az előkészítő szakaszt jelentő kifejezések között. E körben a nyomozás-vizsgálat, előnyomozás-elővizsgálat szavak kapcsolódásai és használatuk keltik fel a figyelmet.

A büntető anyagi és eljárásjogi jogalkotás több nekirugaszkodással haladt simának nem nevezhető útján, míg elérte a változásokban áttörést hozó 1878. évi V. törvénycikket, a magyar büntető törvénykönyvet a büntettekről és vétségekről, valamint a bünvádi perrendtartásról szóló 1896. évi XXXIII. törvénycikket.

„Azon törvényes rend és mód, melynél fogva a büntények kinyomoztatnak, elitéltetnek, és az itélet által kitüzött büntetések végrehajtatnak, büntetöeljárásnak, a büntények kinyomozására adott nyilvános hatalom pedig büntetö törvényszéknek neveztetik." A vizsgálat kétféle: 1. Általános, ami irányul mind a büntény, mind az elkövető személyének kivizsgálására. Ekkor még nincs személy, aki gyanúba vehetö. 2 . Különös, midőn valamely gyanúban lévő személy ellen intézik. ${ }^{16}$

Szlemenics szerint a fenyítő vizsgálat vagy nyomozás az a bírói tétel, amelynél fogva a fenyítőbíróság a büntettet és annak szerzőjét kinyomozni iparkodik. Lehet általános és bizonyos személy ellen intézett. ${ }^{17}$

Az általános vizsgálat a tárgyi, a különös az alanyi tényálladék ${ }^{18}$ kiderítésére irányult. Később megkülönböztették az előnyomozást, amely a tárgyi tényálladék, és a rendes vizsgálatot, amely kizárólag az alanyi tényálladék kiderítését szolgálta. ${ }^{19}$

Pauler az előkészítő szakaszban teljesítendő elővizsgálatról ${ }^{20}$, illetve vizsgálatról ${ }^{21}$ csekély eltéréssel ugyanazt írta, nevezetesen hogy alattuk ,, a bün-

\footnotetext{
16 Kassay Adolf: i. m. 82. o.

17 Szlemenics Pál: i. m. 213. o.

18 A vizsgált időszakban a tárgyi tényálladék és az alanyi tényálladék kifejezések voltak használatosak és csak a századforduló közeledtével honosodott meg a helyes meghatározás, azaz a tényálladék tárgyi elemei és a tényálladék alanyi elemei formulák.

19 Székács Ferenc: i. m. 12. o.

20 A tárgyi tényálladékra vonatkozó általános vizsgálatot 1864-ben szorosabb értelemben vett elővizsgálatnak nevezte. Pauler Tivadar (1864): i. m. 324. o.

21 A tárgyi tényálladékra vonatkozó általános vizsgálatot 1873-ban szorosabb értelemben vett elővizsgálatnak, előnyomozásnak nevezte. Pauler Tivadar (1872): i. m. 358. o.
} 
tettek perbeli tárgyalására szükségelt adatok kinyomozása és egybegyüjtése értetik. Mint a büntetö per anyagi elökészitése, a tényálladék megállapitásá$r a$, a tettes és társai felfedezésére, a tett minden nyomós körülményei kipuhatolására terjed, és ily értelemben magában foglalja" az általános és a különös vizsgálatot. ${ }^{22}$ Álláspontja szerint utóbbiak között elméletileg megvonható határvonal, de számos esetben nem tartható fenn. Például az önfeljelentő esetében, vagy amikor a tárgyi tényálladék csak bizonyos személy elleni intézkedéssel - házkutatás által - állapítható meg.

A nyomozást, vizsgálatot végzők köre is változást mutat az érintett idöpontoktól kezdve. Megyékben korábban nyomozást/vizsgálatot folytattak a szolgabírák, az esküdtek és a tiszti ügyész. Halasztást nem türő esetben, föként ha a késedelem veszéllyel járt, helybeli elöljárók, mezei biztosok is végeztek előnyomozási cselekményeket, amelyekről az illetékes szolgabírót a felvett jegyzőkönyv beterjesztésével értesíteni tartoztak. Elővizsgálati cselekmények elvégzése céljából csendbiztosokat esküdti ranggal is felruházhattak. ${ }^{23} \mathrm{~A}$ szolgabírák mindkét időszakban végeztek nyomozást. 1872 előtt együttesen rendőri és bírói teendőket is elláttak, a változás után bünügyi nyomozásokban a tevékenységük rendőri cselekménnyé vált.

Szabad királyi városokban a kapitány (1870-től rendőrkapitány), a tiszti ügyészek, egyes bírósági tagok hajtottak végre előnyomozásokat, elővizsgálatokat.

1872-től az előkészítő szakasz „szabályozott” főszereplőjeként jelent meg a vizsgálóbíró. Már korábban is használták e kifejezést, és a kiküldött vizsgáló bizottság/bíróság formákat is.

Vizsgálóbírákat, rendszerint a törvényszéki bírák sorából, csekélyebb fontosságú esetekben a jegyzők közül, a törvényszék elnöke nevezett ki. A járásbíróságok teljesítették a büntetővizsgálatot a járásukon belül felmerülő azon bünügyekben, amelyek a törvényszék hatásköréhez tartoztak, ha a törvényszék e bünvizsgálatok vezetését saját vizsgálóbíróra nem bízta. ${ }^{24}$

\footnotetext{
22 Nyomoz: 1. Büncselekmény tettesét, körülményeit felderíteni igyekszik; 2. Valami után kutat. Nyomozás: Az az eljárás, amellyel valamely (bün-) ügyben nyomoznak. Keresés, kutatás. Magyar értelmező kéziszótár. Második, változatlan kiadás. Akadémiai Kiadó, Budapest, 1975, 1022. o.; Vizsgál: 1. Alaposan, részletesen megnéz, figyel. Alaposan tanulmányoz valamit, hogy mivoltáról, állapotáról tudomást szerezzen. Vizsgálat: 1. Az a cselekvés, hogy valamit (valakit) vizsgálnak. Nyomozás adatainak felülvizsgálata a tárgyalás előkészítésekor. Uo. 1517. o.

23 Kitűnő példája a nyomozó csendbiztosoknak Osváth Pál sárréti csendbiztos, aki e posztot 1859-től 1882-ig töltötte be. Ebbéli tevékenységéről a Közbiztonságunk múltja és pandur korom emlékei (Fritz Armin, Budapest, 1905) címü könyvében írt gazdag részletességgel.

24 1871:XXXI. tc. 6., 16. §
} 
Az előnyomozások jelentős közremüködői voltak a közbiztonsági tisztviselők és a közbiztonsági közegek, akik kötelesek voltak a helyszínt, változatlan fenntartása mellett, biztosítani; az elkövetőt szökés veszélye esetén elfogni, előállítani; három nap után, ha vizsgálóbíró nem jelent meg, a járásbíróság elé állítani; a tanúkat felkutatni és előrendelni; vizsgálóbíró megjelenése esetén rendelkezéseit teljesíteni. Az előnyomozásról vezetett jegyzőkönyvbe az eljárás idején felmerülő s a vizsgálatra vonatkozó minden körülményt pontosan rögzíteni kellett. A közbiztonsági tisztviselők által tett előnyomozás mind a lényeg, mind az alak tekintetében a vizsgálóbíró által megbírálandó, szükség esetében kiegészítendő, illetve ismétlendő volt. A büntett elkövetésén kapott egyént bárki elfoghatta, az elfogó azonban köteles volt őt haladéktalanul a legközelebbi község elöljáróságának vagy közbiztonsági közegnek átadni. ${ }^{25}$ Az ügyész előnyomozások megtételére a közbiztonsági közegeket megkereshette, ők a megkereséseket a bírói felelősség terhe alatt teljesíteni tartoztak. ${ }^{26}$

\section{Pécs-Baranya közbiztonsági közegei}

Baranya megye hét járásra - pécsi, baranyavári (dárdai székhely), mohácsi, pécsváradi, hegyháti (sásdi székhely), siklósi, szentlőrinci - és Pécs szabad királyi városra tagozódott. A 438 lakhelyként nyilvántartott településen 45952 házban 285506 lakos élt. A székhelyen, Pécsett, 2969 házban 23863 an laktak, nemzetiségüket tekintve magyarok, németek és horvátok. A városban állomásozott hozzávetőlegesen 1400 fönyi katonaság. ${ }^{27}$

A megyei közbiztonsági közegek szolgálati utasítása ${ }^{28}$ szerint a közbiztonsági személyzet csendbiztosokból, pandúrkáplárokból és közpandúrokból állt, közvetlenül a megyei első alispán alárendeltségében. ${ }^{29} \mathrm{~A}$ járásokban alkalmazott pandúrkáplárok és közpandúrok a járásbeli föszolgabíró rendelkezése alatt álltak. Kötelesek voltak a közigazgatás és az igazságszolgáltatás

\footnotetext{
25 Hármaskönyv II. 32. cím; Sárga könyv 19-41. §.

26 1871:XXXIII. tc. 21. §

27 A Magyar Korona országainak helységnévtára. Athenaeum, Budapest, 1873

28 Baranya vármegye részéről 1868. évi október hó 5-én folytatólag tartott bizottmányi közgyülés 1862. sz. a. kelt határozatával a megyei közbiztonsági közegek számára megállapított szolgálati utasítás. Nyomtatott ifj. Madarász E. Gyorssajtóján, Pécs, 1868, 8. o. Ugyanekkor fegyelmi szabályokat is megállapítottak. 7. o.

29 A vármegyei létszám 1869-ben három csendbiztosból és száztizenhárom gyalogpandúrból állt. A járásokban egy-egy pandúrkáplár vezetésével tíz-tizenöt közpandúr teljesített szolgálatot, két-két járásonként csendbiztos parancsnoksága alatt. Fegyveres személyek voltak még a börtönőrök, egy föispáni és négy irodai huszár, három központi és hét járási tiszti csatlós.
} 
körül a fölöttes járásbeli tisztviselő utasítását végrehajtani. Egyebek között fó teendöik között szerepelt: az önmaga által észlelt vagy tudtára adott eseteket a járásbeli tisztviselőnek bejelenteni s a tetteseket szorgosan nyomozni; a tetten ért gonosztevőket, rablókat, gyilkosokat, gyújtogatókat, csalókat, tolvajokat, az erdőkárosítókat, a jogosulatlanul fegyverrel járókat, a kóborlókat és egyébként gyanús, magukat igazolni nem tudó személyeket befogni, illetve letartóztatni; a hatóságok által körözött személyekre és tárgyakra figyelemmel lenni.

A lopások és rablások meggátlására, bekövetkezésük esetén nyomban történő nyomozására, a tettesek üldözésére, minden állomásnál legalább két pandúr, egyik kijelölt őrvezető, a kiszabott körben cirkálni volt köteles. Ha az őrjárat lappangó csavargókról vagy fegyveres rablókról értesült, nyomban üldözöbe vette öket, és az öt kiküldő, valamint a legközelebbi pandúrállomást értesítette, akkor is, ha az a szomszéd járásban vagy megyében volt.

Magánházban történő kutatásra járásbeli tisztviselő különös megbízása folytán voltak jogosultak, és a házkutatás az illető község bírája vagy egyik esküdtje jelenlétében történhetett. Kivétel volt ez alól, ha a lakók életének, vagyonának megóvása szükségessé tette, vagy a házba szökött gonosztevőt üldöztek.

A fegyelmi szabályzat szerint az elfogott rablót vagy tolvajt megkötözve, a legközelebbi községi bíróhoz kellett vinni s ott átkutatni. A nála talált pénzt, fegyvert, lopott tárgyat az elöljáróság jelenlétében el kellett venni, arról az elöljáróság tartozott a községi pecsét alatt jegyzőkönyvet felvenni. Az elfogottnál talált dolgokat vele együtt a vizsgálóbírónak kellett átadni. A szolgálati utasítás nagymértékben tükrözte a vármegye királyi biztosa által négy évvel korábban kiadott utasítás rendelkezéseit. ${ }^{30}$

Végeztek továbbá közbiztonsági tevékenységet a községi rendőrségek tagjai is.

Pécs szabad királyi városban önkormányzati rendörség ${ }^{31}$ müködött. A város hatóságának gyakorlói között szerepelt a községi bíróság és a rendőrség vezetője is. A városkapitány, majd rendőrkapitány feladatai között feltüntették a büntények megakadályozását, azok elkövetőinek nyomozását, az elővizsgálatok teljesítését és az illetékes helyre való feljelentését.

30 Szolgálati utasítás a Baranyamegyei csendbiztosok, s a közbiztonsági közegek (pandúrok) számára, 295.eln. szám alatt, 1864. március 1-jén. A megyei pandúrságról részletesen lásd Ernyes Mihály: Baranyai rendőrségek. Teromo Bt., Pécs, 2004

31 1870-ben a rendőrkapitány alárendeltségében szolgált három rendőri főbiztos, két rendőri fogalmazó, három rendőri albiztos, egy őrmester, két káplár és harmincnyolc közrendőr. Az önkormányzati rendőrségről bővebben lásd Ernyes Mihály: Pécs város rendőrsége. Teromo Bt., Pécs, 2003 


\section{Fogva tartás}

A rendőrség a tetten ért elkövető elfogásán kívüli esetben is előzetes fogságba helyezhette a vádlottat, de arról a bírósághoz haladéktalanul jelentést kellett tennie, a foglyot pedig három napon belül oda átkísérni. A vizsgálóbíró döntött a letartóztatásról. ${ }^{32}$ Ha nem követte vizsgálati fogság ${ }^{33}$, nyolc nap elteltével a törvényszékhez volt köteles fordulni a letartóztatás fenntartása érdekében, amit szükség esetén nyolcnaponként ismételni kellett. Letartóztatás/előzetes letartóztatás esetén a gyanúokok még nem elég nyomatékosak a vizsgálati fogság elrendeléséhez. Utóbbi esetében két okba tömöríthetők a feltételek: 1. a vizsgálat meghiúsításának a veszélye; és 2 . a szökés veszélye.

A fogágba helyezéskor az őrizetes ruházatát átvizsgáltak, különös figyelemmel a szökést elősegítő tárgyakra, eszközökre - pénz, fegyver, egyéb -, a személyleírását rögzítették, hogy esetleges szökése esetén elfogatása érdekében körlevelet bocsáthassanak ki. ${ }^{34} \mathrm{~A}$ fogva tartás lehetőségét megalapozó büncselekményi kört számos törvényhely tartalmazza. ${ }^{35}$

A fogva tartásról értesíteni kellett hadkötelezettség vonatkozásában az illetékes katonaságot, nagyobb szolgáltatóknál dolgozók vagy állami tisztséget betöltők esetében az elöljárót, a munka folyamatosságának biztosítása érdekében. ${ }^{36}$

\footnotetext{
32 Sárga könyv 25. §

33 A vizsgálati fogság elrendelésének okai: a) Ha az elkövetett büntett, vagy amivel a terheltet vádolják a fennálló törvények szerint halállal vagy a gyakorlat szerint legalább ötévi börtönnel büntetendő; b) Ha a vádolt intézkedései után annak megszökési szándéka alaposan vélelmezhető; c) Ha a vádlott nem bír állandó lakással; d) Ha alaposan lehet tartani attól, hogy szabad lábon hagyása esetében a bűntett nyomait elhárítja vagy a vizsgálat eredményét a büntársakkal, bünrészesekkel, segélyezőkkel, orgazdákkal, úgy a tanukkal való összebeszélés által meghiúsítja, úgyszintén, ha veszélyes fenyegetései folytán alaposan lehet tartani, vagy egyéb adatokból kitünnék, hogy szabad lábon hagyatása esetében, más büntettet követne el. A vizsgálati fogság elrendelése írásba foglalt határozatban mondandó ki. Sárga könyv 45-46. § 34 Kassay Adolf: i. m. 84. o.; Székács Ferenc: i. m. 34. o.

35 Pauler felsorolása szerint ,a közbátorság érdekében foganatosítható letartóztatások alapjául szolgálhatnak a következők: a) kik felségárulás vagy felségsértés vádja alatt állnak azok börtönükből idéztetnek (1715. 7. 1723. 5.) b) kik súlyosabb büntett elkövetésén: gyilkosságon, gyújtogatáson, tolvajságon, rabláson, rablógyilkosságon, erőszakos házasságtörésen éretnek, vagy folytonos üzésben elfogatnak (HK: I.8. III.20. 1723. 5.) c) szökevény katonák (1598. 31. 1601. 13.) d) számadással tartozó tisztek és szolgák, kik ebbeli kötelezettségük mulasztásával szökni készülnek (1435. 6. 1471. 2. 1486. 33.1554. 20. 1622. 65. 1723. 65.), e) kóborok, tudvalevő bűntettesek és társaik, kik lakásukon kívül alig bírnak egyéb jószággal (HK: II.68. 1655. 38. 1687. 14.) f) mezei kártevők ugyanazon feltétel alatt, vagy ha tetten kapva vagy folytonos üldöztetésben elérve, zálogot nem adnak (1840. 9. §. 17. 22.) g) váltóhamisítók (1844. 6. §. 28.) h) csalárd vagy vétkes vagyonbukottak, ha elszökésüktől tarthatni 1844. 7. §. 5.) végre i) kik törvényesen megidézve a bíróság előtt meg nem jelennek (1563. 48. 1625. 13.)". Pauler Tivadar (1873): i. m. 392. o.

36 1863. március 30. 4522. sz. udvari rendelet. Az 1864. június 18-ai 49074. számú helytartótanácsi intézkedés szerint vaspályatársulat esetén elöljáró az állomásfőnök.
} 


\section{Vizsgálati és bizonyítási eszközök, bizonyítékok}

A felhozott szakirodalmi szerzők némiképp eltérően közelítették meg az igénybe vehetö eszközöket, illetve a felhasználható bizonyítékokat, az Ideiglenes eljárási szabályzat pedig azt tudatosította, hogy a bizonyítékok bizonyító erejét a bíróság állapítja meg. ${ }^{37}$

Szlemenics szerint a fenyítő vizsgálat eszközei: a bírói szemle; a házkutatás; rab- és tanúvallatás; szükség esetén szembesítés. A rendszerinti bizonyítékok a rab vallomástétele, a tanúvallomások és a büntett gyanújelek, a rendkívüliek büntetöügyek vonatkozásában megszüntek. A gyanújelek olyan körülmények, amelyekből a büntett szerzőjét gyanítani lehet, vagy legalább gyanítani szokás. A való gyanújelek valóságos és alapos összefüggést mutatnak a büntettel és annak szerzőjével. A félszeg gyanújeleknek (álomlátás, jóslás) nincs közük a büntetthez, nincs bizonyító erejük. A segéd gyanújeleknek (gonosztevővel társalgás, elpirulás, hasonló büntettben részvétel) csekély bizonyító erejük lehet. ${ }^{38}$

Pauler bizonyítási eszközökként sorolta fel a bírói szemlét; az önvallomást; a tanúkat; az okiratokat; a bünjelenségeket vagy gyanúokokat. Kitért arra is, hogy hajdan alkalmazták az istenítéletet; a kínvallatást; az ijesztgetést; az eskütársakat; a tisztítóesküt, amelyek igazságtalansága és célszerütlensége azonban általában elismert volt, $\mathrm{s}$ többségük tiltottá is vált. Miután a vádlottak bünösségét vagy büntelenségét sok esetben közvetlen bizonyítás útján nem lehet kideríteni, a bünjelenségek fontossága és szükségessége kétségtelen. Közéjük tartozók a büntettre ingerlő okok (harag, bosszú, szerelem, és a tettből várható előnyök); a büntettre mutatkozó hajlam (hasonló büntény korábbi elkövetése, másoknak arra csábítása); a bünözési akarat nyilvánítása (tudakozódás, fenyegetés, eszközbeszerzés); feltünő viselkedés (öltözet, előkészület, kísérlet); valaki jelenléte az elkövetés helyszínén, annak időpontjában; dolgainak ott találása; olyan eszköz birtoklása, amellyel a büntettet elkövették; hasonlatosság a sértett vagy tanú által adott személyleíráshoz. Az utólagos jelenségek pedig büntettre utaló jelek, változások (sebek, véres foltok, szennyeződések); sértett tárgyainak birtoklása; büntett nyomainak megsemmisítése; szökés, rejtőzködés; törvényszéken kívüli beismerés; tanúk és a sértett hitelesített vallomása. A mentő vagy ellenjelenségek a vádlott jó hírneve; bűnözési indokának hiánya; visszatartó okok léte; távollét a büntett he-

\footnotetext{
37 Sárga könyv 6. §

38 Szlemenics Pál: i. m. 214., 240., 247. o. Utalt a Helytartótanács 1818. december 15-én kelt 34329. számú intézkedésére, amely kimondta, hogy semmi ne hiányozzék, ami a büntett tárgyi tényálladékának, valamint a bünösségnek és betudásnak meghatározásához szükséges.
} 
lyétől az elkövetés idején (alibi). Szükséges, hogy a tett és a vádlott személye közötti összefüggésben okszerüen kételkedni ne lehessen. A halálbüntetésre nézve és a rögtönbírósági eljárásban közvetlen bizonyíték szükséges. ${ }^{39}$

A bizonyítékok a végtárgyaláson (a bizonyítási eljárás során) elhangzottakból álltak elő, csakis ezek felhasználásával születhetett meg a bíróság ítélete. Az előnyomozás és a vizsgálat során a bizonyítékoknak a gyüjtése történt meg, felvételére a végtárgyaláson került sor. Bizonyíték felvételére mégis sor kerülhetett olyan esetekben, amelyek a végtárgyaláson nem ismételhetők meg. Ilyenek például a nyomkutatás és a boncolás. Tanúk vonatkozásában olyan kivételes esetekben, amikor tartani lehetett attól, hogy végtárgyalásra a tanú idézése nem lehetséges. Ilyenkor a tanút a vizsgálóbíró előzetesen megeskette. Szükség esetén hitelesítési tárgyalás volt tartható, amelyet általában az ügyész indítványozott. ${ }^{40}$

\section{A pécs-baranyai nyomozás-vizsgálat gyakorlatából}

Az előkészítő eljárás során a bizonyítékoknak a gyüjtése történt meg a vizsgálóbíró és a nyomozásban részt vevő rendőri hatóságok által. A büntetőeljárás megindítása alapulhatott a bíró öntapasztalásán ${ }^{41}$, tettenérésen, önfeljelentésen, szárnyaló híren ${ }^{42}$, feljelentésen. Névtelen feljelentésekre intézkedni nem kellett ${ }^{43}$, esetleg büntettre vonatkozó határozott útmutatás esetén az, annak kipuhatolására adhatott okot. ${ }^{44}$

39 Pauler Tivadar (1873): i. m. 447-449. o.

40 A Pécsi Királyi Törvényszék 1873. február 28-án tartott zárt ülésén a vádlottak vallomásait hitelesítette, mivel a vizsgálóbíró ezt kérte. Az ülést vezető elnöknek szóbeli jelentésében elmondta, hogy a vizsgálatot lefolytatta, amelynek eredményeképpen a rablógyilkosság tettesei kipuhatoltattak. A vallomások előzetes hitelesítése azért szükséges, mert a vármegyei fogház oly hiányos berendezéssel bír, hogy a vádlottakat hosszabb ideig külön elzárni s így az egymással való érintkezéstől megóvni nem lehet. Ekképpen félö, hogy vádlottak a tettet beismerő vallomásukat összebeszélés folytán vissza fogják vonni. MNLBaML 1873/V.211.

41 S. Ivo vétkes emberöléssel vádolt, kökényi lakosokról B. Mátó és B. Stipo 1875. április 17-én Kökényben községi bizonyítványt írtak alá. Mivel az nem a valóságot tartalmazta, ezért ellenük a Pécsi Királyi Törvényszék bűnvádi előnyomozást rendelt el az elsőfokú ítéletében. „Beismerték, hogy tudták, vádlott büntetve volt, minthogy a beperesített és általuk aláírt erkölcsi bizonyítványban, annak ellenkezője állíttatik, ellenük hamis okirat kiállítása miatt bünvádi eljárást kellett elrendelni." MNLBaML 1875/V. 410.

42 Közhír eredetét nyomozni, alaposságát vagy alaptalanságát kikutatni és ahhoz képest az előnyomozás iránt intézkedni kellett. Pauler Tivadar (1873): i. m. 356. o.

$43 \mathrm{Az}$ árulkodók jelentsék be saját nevüket, hogy hamis vádaskodás esetére megfelelő büntetésben részesüljenek. Névtelen följelentésre semmit sem kell adni. 1805:V. tc. 1-2. §

44 Pauler Tivadar (1873): i. m. 356. o. 
Önfeljelentéssel indult $B$. Simon mohácsi lakos ügye. ${ }^{45}$ Nevezett 1871 . december 22-én, pénteken este háromnegyed nyolc körül munkából hazaérkezve lakásán találta Cs. Ivó mohácsi lakost, akit több baltaütéssel megölt. Tette után a barátjához ment, akinek elmondta cselekedetét, majd a kislányát otthagyva távozott. Jelentkezett a szomszédságban lakó Kunóvszky Márton megyei pandúr őrvezetőnél, aki őt és feleségét elfogta, az elkövetés eszközét lefoglalta.

Az intézkedéséről készült hivatalos jelentésnek minősített jegyzőkönyvet 23-án reggel Varga Aladár esküdt vette fel a Mohácsi Járási Szolgabíróságnál. „Reggel 9 órakor Kunóvszky Márton megyei foglár ${ }^{46}$ örvezetö a bíróság elött megjelenvén szóval elmondta. Ma éjjel Cs. Ivó mohácsi lakos B. Simon házánál, B. Simon által állitólag, mert Cs. Ivót nejével találta, fejszével agyonvágta. Ennél fogva B. Simont és nejét bezártuk. Állitólag ezen fejszével történt az agyonütés."

Önfeladását a bíróság enyhítő körülményként értékelte „,Másodszor odahagyva házát kis gyermekével futott barátjához megvallva neki, hogy Cs. Ivót agyonütötte”. Barátjának annyit mondott: ,Nagy baj van, agyonütöttem a Horkát."

Önmagát jelentette fel A. Lörinc ${ }^{47}$ jakabfalvi lakos, aki 1871. augusztus 12én, szombaton reggel kilenc óra körül fogadó atyját több fejszeütéssel megölte. Cselekménye után a lakószobát bezárta, és a községi bíróhoz ment. Öt nem találta otthon, ezért azonnal átment Villányba, és ott az esperesnek elmondta tettét, majd vele bement a jegyzőhöz. Neki is elmondta, mit tett, és átadta a lezárt ajtó kulcsát. A jegyző a kulcsot átvette, A. Lőrincet pedig letartóztatta. A vizsgálatot Bauer János megyei esküdt folytatta le. A tényálladékban rögzítette egyebek között, hogy „Folyó év és hó 12-én a villányi jegyzőségtöl érkezett hivatalos jelentésben bejelentetett, hogy A. Lörinc fogadó atyját S. József jakabfalvi lakost meggyilkolta, kérvén vizsgálatot. Ezen jelentés folytán Horvát Mór szolgabiró úr jelenlétében másnap, vagyis augusztus 13-án az orvosi vizsgálat és boncolás, úgy ennek következtében a befogatott illetöleg önként jelentkezett A. Lörinc gyilkos ellen a bünvizsgálat megkezdetett."

Feljelentés alapján indult eljárás $P$. János ${ }^{48}$ ellen, aki 1870. szeptember 12én, hétfön 17 óra körül a Szentlőrinc-Pécs út mentén G. Jánost olyan súlyo-

\footnotetext{
45 MNLBaML 1872/V.15. számú irat, Pécsi Királyi Törvényszék.

46 A pandúrokat említették foglároknak is. Kunóvszky tanúkihallgatásakor, december 31-én, önmagát megyei pandúr őrvezetőnek nevezte.

47 MNLBaML 1872/V.442. számú irat, Pécsi Királyi Törvényszék.

48 MNLBaML 1872/V.344. számú irat, Pécsi Királyi Törvényszék
} 
san bántalmazta, hogy másnap belehalt a sérüléseibe. „Öt óra tájban Troll Ferenc pécsi kanonok egy félig agyonvert embert talált az országúton és tovább menve egy másik emberrel találkozott, kit a büntettesnek lenni lévén ez irányban azt megszólitotta. Ki ezen megszólitásra azonnal bevallotta, hogy az országúton fekvö embert ö verte le. Troll kanonok ezen embert felvette a kocsira és Németürögben a községi jegyzőnél letette, átadta."

A pécsi járás főszolgabírójához Brüsztle József olaszi plébános tett írásban feljelentést 1870 . november 5-én $P$. Anna ${ }^{49}$, néhai $W$. János özvegye ellen, aki az előző éjszaka szült gyermekét megölte. „,Múlt éjjel törvénytelen leánygyermeket szült fivére házában, Birjánban, és pedig alattomban kiment az udvarba és ott megszülvén a gyermeket, azt azonnal megölte és szalmába dugta. Fivére észrevévén e gonosz személyt kezdette vallatni. Ki végre a sok unszolásra behozta a gyereket holtan. Miután a kisdedet meg kell vizsgálni orvosilag, nehogy a vizsgáló bizottmány, e rossz idöben, képtelen legyen kijönni, a megölt gyermeket Pécsre vitetni rendeltem. A nöt pedig néhány nap múlva, midőn felüdül, méltóztassék Pécsre vitetni és a fenyitö törvényszéknek átadni, mert ez egy istentelen és feslett életü személy."

Ismeretlen tettesek által elkövetett rablógyilkosság miatt indult eljárás, mivel 1873. február 11. éjjelén Cinderibogádon meggyilkolták és kirabolták K. Istvánnét. A támadást túlélő Sz. Katalin, a rablók fenyegetése ellenére, fellármázta a falszomszéd ház lakásában élő $S$. Jánost, aki meghallgatván a történteket, nyomban szólt G. Józsefnek, majd a falu bírójához sietett.

Megkocogtatta az ablakot és közölte, hogy a néhai református lelkész özvegyét kirabolták s talán meg is ölték. A bíró felöltözött és az áldozatok házához ment. A folyosóablak rongált állapotának észlelésével azonnal meggyőződött a betörés megtörténtéről, a hálószobába belépve pedig látta, hogy ágyában halva fekszik az özvegy papné, K. Istvánné. Kis Bíró József községi bíró ezután kikérdezte Sz. Katalint, több bútort és ajtót lepecsételtetett, a ház elé az egyházközség segítségével őrséget rendelt, majd jelentést tett a körjegyzőnek.

Február 12-én délelőtt 11 órakor Cinderibogádon Kohárits József magyarmecskei körjegyzö, Nagy Sámuel bogádi esküdt és Bezenkó József újmindszenti bíró jelenlétében Kis Bíró József elmondása alapján nyomozati jegyzőkönyvet vett fel, amelyet soron kívül juttatott el a szolgabíróhoz.

49 MNLBaML 1872/V.413. számú irat, Pécsi Királyi Törvényszék. 
Németh Ignác szolgabíró a következő napon mintegy féloldalnyi terjedelmủ tényálladék leírásával elkészítette a feljelentést, amelyet a Szentlörinci Királyi Járásbíróság a Pécsi Királyi Ügyészséghez továbbított. ${ }^{50}$

A tényálladék szerint két fö behatolt ,, a meggyilkolt alvószobájába hol a magasabb egyén a meggyilkolt ágyához lépett, azon suttogó hangon kiejtette szóval »meg kell halnod ma« még az alacsony szürös, unoka húga ágyához ment és azt fenyegetözés mellett hallgatásra intette. Az özvegy tiszteletes aszszonyt a magas kezével megfojtotta. Késöbb a két rablógyilkos elövévén a meggyilkolt feje vánkosa alól a kulcsokat, azokkal mindent felnyitottak és amit, papirt vagy pénzt találtak, magukkal vitték. De elvittek egy bör nöi cekkert is, melyben Sz. Katalin szerint egy levélboriték is volt, melyben Kisfaludy István ügyvéd aláirásával, néhány szóval egy küldemény átvétele igazoltatik. Ezen boritékban volt tudtával két 1 forintos bankjegy."

Lobmayer István királyi ügyész február 15-én indítványozta a Pécsi Királyi Törvényszék fenyítő osztályánál a vizsgálóbíró haladéktalan kiküldését. Két nap múlva a törvényszék végzésében - a nyomozás és a szükséges vizsgálat helyszínen történő elvégzésével - különös meghatalmazással a tettesek rögtöni befogására, a korábban számtalan súlyos büntény elkövetőjét felderítő, rendkívül komoly tapasztalatokkal rendelkező Pilch Antal törvényszéki bírót bízta meg a vizsgálóbírói teendők ellátásával.

A rablógyilkossághoz szorosan kapcsolódott egy szőlőhegyi pincebetörés-sorozat, amelynek nyomozásában is aktív szerepet vállaltak a pandúrok. A vizsgálóbíró által készített tényálladék szerint „,Cinderi-Bogádon lakó özvegy K. Istvánnén elkövetett rablógyilkosság tettesei f. é. február 26-án befogatván, ama vidék lakosai oly meggyözödésre jutottak, hogy a múlt télen az ózdi és szentmártoni hegyen elöfordult pincebetörések is ugyanezen büntársaság által követtettek el. Ezen hír folytán a megyei közbiztonsági közegek a nevezett tettesek rendes tartózkodási helyét Krausz mindszenti bérlö szérüs kertjét kutatás alá vévén, ill. egy szalmaboglyában a bünjelekként XIII a-b-ig lefoglalt tárgyakat találták, melyek kárvallottak pincéjéböl lettek ellopva."

Rendőri jelentés ${ }^{51}$ alapján indult az eljárás azon kettős gyilkosság ügyében, amelyben a bíróság a tárgyi tényálladék bizonyítását is látta a rendőrbiztos intézkedésében. „A tárgyi tényálladék bizonyitott a rendőri jelentés által, mely szerint a helyszinen megjelent biztos a becsukva volt szobaajtó zárát kifeszittetvén, látta G. Ferencet az asztaltól négyujjnyi távolságban a gerendá-

50 MNLBaML 1873/V.211. számú irat, Pécsi Királyi Törvényszék. 51 MNLBaML 1873/V.658. számú irat, Pécsi Királyi Törvényszék. 
ra és P. József 9 éves fiút a ruhaállványra felakasztva lógni. ” A vádlott szölöjében két alkalommal is végeztek kutatást, amelyben szintén eredményes volt a rendőri közremüködés. ,Egy feneketlen hordóban oly ingóságok találtattak, melyek a jegyzökönyv szerint az ott eszközlött elsö motozás alkalmával még ott nem voltak. Különösen pedig a meggyilkoltnak, munka elött viselt órája és gyürüje."

Az élet és a testi épség elleni büntények esetében kiemelkedő szerepet töltött be az orvosi közremüködés. Azon haláleseteknél, amelyeknél büntett gyanúja forgott fenn, bírói halottszemlét kellett tartani, ami állt a holttest megszemléléséből és boncolásából. Kétségen kívül helyezendő volt a holttest azonossága. Ha az ismeretlen volt, leírását nyilvános lapokban közzé kellett tenni. A szemle a külső leírással kezdődött, ez után következett a holttest felnyitása. A látlelet folytán szerkesztett véleménynek mindig a tekintetben kellett nyilatkoznia, mi volt a halál legközelebbi oka, és miböl származott. ${ }^{52} \mathrm{~A}$ vizsgált ügyekben a halottszemlét, illetve a boncolást rövid idő elteltével elvégezték, az orvosi véleményt elkészítették.

A K. Ferenc sérelmére elkövetett emberölés ügyében ${ }^{53} 1869$. október 28án 15 és 16 óra között, a sérülést követően mintegy 12 óra elteltével, végezte el a boncolást $d r$. Mantlem Ödön, Pécs szabad királyi város föorvosa és $d r$. Mortány Antal alorvos. ,,Volt munkás hullája felett, ki állitólag e napon hajnalban fejbe veretett és rá nemsokára meghalt.” A november 2-án keltezett orvosi vélemény szerint „Ezen hulla boncolatából kiviláglik, hogy az egyén valószinüleg egy tompa eszközzel a fejre két ütést kapott, melyek a fejtakarókon keresztül, eröszakos behatások által a csontokat behorpasztották és eltörték. Továbbá ezen ütések rossz következményei törés és repedés alakban a koponya fenekéig terjedvén, részint agyvér torlódás és utána következö érszakadás folytán, részint az állomány és agyhártyákban agy rázat következtében agyhüdést okoztak."

B. Simon ügyében Cs. Ivó boncolását az elkövetés utáni napon, Kerese Imre szolgabíró felszólítására végezte el a meggyilkolt lakásán $d r$. Trempacher Mátyás járásorvos és dr. Serly Sándor, Varga Aladár esküdt jelenlétében. Az azonnal elkészített orvosi vélemény szerint „A vizsgált egyén eröszakos halállal múlt ki. Az l-es számú koponyasértés okvetlenül halálos”.

\footnotetext{
52 Az 1803. május 17-én kelt 11371 sz. helytartótanácsi intézkedés szerint a törvényhatóságoknak, ahol szükségesnek mutatkozik, kötelező az orvosi látlelet beszerzése (emberölés, súlyos testi sértés). A hullaszemlére vonatkozóan részletes elöírásokat tartalmaz a Helytartótanács által 22985. szám alatt 1864. május 18-án kiadott intézkedés.

53 MNLBaML 1873/V.658. számú irat, Pécsi Királyi Törvényszék.
} 
P. Anna ügyében a jegyzőkönyv szerint 1870 . november 5-én, a szülés napján, Pécsett folyt le a boncolás Pilch Antal megyei esküdt és „több mások” jelenlétében. Előzmény: ,Brüsztle olaszi plébános úr ezen gyermekhullát tekintetes Forray föbiró úrhoz ezen jelentéssel küldé be, miszerint ezen gyermek P. Anna által lett volna szülve, megölve és a szalmába elrejtve.” Dr. Mendl Lajos megyei fogházi és járásorvos november 7-én keltezett véleménye szerint ,Az újszülött gyermek éretten és életképesen született [...] a gyermek élt és lélegzett [...] a halál, fulladás által okoztatott valószínüleg”.

Bánffay Simon tiszti föügyész hivatalos megkeresése folytán az orvosi véleményt $d r$. Visy István megyei II. főorvos felülvizsgálta. Az 1871. szeptember 11-én kiadott felülvizsgálati jelentésében rögzítette „Hogy ámbár elismerem miként a boncjegyzökönyv elég gonddal és pontossággal szerkesztetett, mégis a halálnak a jelen esetbeli okának felderitésére elegendö adatokat nem szolgáltatott [...] a tüdön, légcsöben és sziven oly körülményeket találunk feljegyezve, melyek a fulladás általi halált végképp kirekesztik. Miután a boncolást végzö orvos véleményéböl, sem pedig megyei föorvos felülvizsgálati jelentéséböl egész határozottan ki nem derithetö vajon a gyermek eröszakos halállal múlt-e ki, ennél fogva, az összes iratot véleményes nyilatkozat adás végett a Pesti Magyar Királyi Egyetem Orvosi Karához felküldeni határoztatott. " ${ }_{54}$ A december 21-én keltezett levélre a pesti egyetem 1872. február 29én válaszolt. Az orvoskari felülvéleményezések tárgyában tartott tizenegyedik rendes ülésen kialakított álláspont szerint az ,elhanyagolt ápolás folytán az elegendö meleg hiányát kell az életerök kimerülése, s így a halál okának tekintenünk".

A Sárga könyv rendelkezései szerint: „Ha gyilkosság vagy emberölés büntettének gyanúja forog fenn, a hulla az eltemetés elött szemlélendö meg, és ha idegen kéz által eszközölt eröszakos halál gyanúja a szemle által sem hárittatnék el, a hulla felboncolandó. Ha pedig az eltemetés után merülne fel az eröszakos kimúlás gyanúja s a tényálladék tisztába hozatala még remélhetö, a hulla ismét kiásatandó. A hullaszemlénél a birón, jegyzökönyvvezetön és az orvosokon, illetöleg vegyészeken fölül még két birósági tanúnak jelenléte is szükséges. A hulla felboncolása nem bizható azon orvosokra, a kik az elhunytat az elhalálozást közvetlenül megelözött betegségben gyógykezelték; mindazonáltal meghívatnak a boncoláshoz a végre, hogy a kórfolyamra nézve felvilágositásokat adjanak. Az orvosi véleménynek a halál okát illetőleg

54 Véleményes nyilatkozatadás végett a Pesti Magyar Királyi Egyetem Orvosi Karához fordulni a törvényszékeknek volt hatáskörük. 
határozott nyilatkozatot kell tartalmaznia arra nézve: vajon a tudomány szerint bizonyossággal vagy legalább valószínüséggel feltételezhetö-e az, hogy a halál a hullán észlelt sértések következménye volt-e?" ${ }_{55}$

Az A. Lőrinc ügyében a boncolási jegyzőkönyv szerint ,Horvát Mór szolgabiró úr által f. é. augusztus hó 12-én felszólittattunk, hogy állitólag A. Lörinc jakabfalui lakos által S. József ottani lakos agyonütött hulláját boncolnók és halála felett szakértöi véleményt adnánk [...] Mely felszólitásra a vizsgálat augusztus hó 13-án reggeli 8 és 1/2 órakor tekintetes Horvát Mór szolgabiró úr és a jakabfalui elöljáróság jelenlétében teljesitetett." A dr. Trempacher Mátyás járásorvos és dr. Serli Sándor által aláírt orvosi vélemény arról tanúskodik, hogy , a vizsgált egyén eröszakos halállal múlt ki [...] a sértések valami kemény, tompa, szegletes és súlyos testtel, nagy erövel okoztattak [...] a halál oka [...] csontbehorpadások által okozott nyomás, részint az ennek következtében létrejött vérömleny és agyrázkódásban keresendö. Melyeket pontos vizsgálat érvet megfontolás után orvosi tudomány elveivel és meggyözödésünkkel megegyezönek lenni nevünk aláirásával bizonyitjuk."

1873. február 13-án az elhunyt K. Istvánné cinderibogádi házában Pupits György járásorvos, a szolgabíró és a községi elöljárók jelenlétében elvégezte a boncolást, amelynek során egyértelmủ megállapítást nyert, hogy a 69 éves, sovány testalkatú áldozatot kézzel fojtották meg. Az orvosi véleményben rögzítették, hogy „Miután a gyilkos az ágyhoz ért, azon ijedve szerencsétlen öregasszonyt torkánál megragadta, a gégét annyira összenyomta, hogy a lélegzetet elzárta és addig tartotta még csak észre nem vette, hogy már nem mozog. Amint a gyilkos, torkát kieresztette, akkorra már az asszony meg volt halva. Ezzel bizonyitom."

A bírói szemle ${ }^{56}$ nyomokat hagyó bủntetteknél főfontosságú tevékenység volt, ami irányulhatott a büncselekmény tárgyára, helyiségeire, eszközeire. Különös felkészültséget igénylő esetekben szakértő közremüködésével kellett végrehajtani. Előbbiek az egyszerü, utóbbiak a minősített szemlét jelentették. Követelmény a mielőbbi lefolytatása, megkezdéséig pedig a változatlan állapot fenntartásáról, ha az nagyobb kár nélkül megvalósítható volt, kötelességszerűen a helybeli elöljárók, csendbiztosok gondoskodtak. A vádlott jelenlétére akkor intézkedtek, ha tőle releváns adatok közlése, illetve tárgyak elismerése volt várható.

$5565-66 . \S$

56 Pauler Tivadar (1873): i. m. 361-363. o.; Szlemenics Pál: i. m. 211. o.; Sárga könyv 54-57. § 
Cinderibogádon Pilch vizsgálóbíró 1873. február 20-án nyolcfôs bizottság (végrendeleti végrehajtó, községi bíró, két községi esküdt, két községi lakos és egy mesterember) élén helyszíni szemlét tartott, amelynek során nyomozási kísérletet is lefolytatott, és egyéb intézkedésekröl is döntött. A csaknem hatoldalas jegyzőkönyvhöz helyszínrajzot mellékelt. A Ceruzával készitett rajz a házról, ahol a gyilkosság történt megnevezésű térvázlat jelöli az utcát, az udvart, az épület helyiségeit, az áldozatok alvóhelyét és az elkövetők mozgási útvonalát. Az észlelt állapot rögzítése mellett néhány alkalommal következtetések kifejtésére is sor került.

A behatolás megkísérlése, illetve a behatolás végrehajtásának helye megállapítható volt, egyúttal jelentős adatokat tárt fel a tetteseknek a helyszínnel való ismeretségére vonatkozóan.

A nyitott folyosóról megközelíthetö, erős vaskapcsokkal zárt ajtón, amely a középső szobába vezetett, meg sem kísérelték a bejutást, a padlás irányából történő bemászás pedig kudarcot vallott. „A nyitott folyosón egy ócska léc lajtorját találtunk, melynek rendes helye a kis fészerben szokott lenni, s mely felett a padlásdeszkák le voltak pecsételve, mert helyükböl kimozdítva találtattak. Megtekintve a nyilásból a padlást, azt találtuk, hogy itt nincs is padlás, hanem csak tetöhosszabbitás, melyen által a padlásra vagy a szobába jutni lehetetlenség, de itt a nyomok is megszüntek. "A kamra udvarra néző ablakát rámástul kiemelték, és a falhoz támasztották. „A fal vályogból lévén a kiemelés könnyü szerrel, de mégis feltünö ügyességgel történt." A kamrát és a középső szobát elválasztó falban úgynevezett kályhalyukat alakítottak ki, amelyben egy sérült cserépkályha állt. A nagyszobába átmenő bizottság előtt „,nyomban az a kérdés támadván, vajon a kályhalyukon bebújhattak-e a tettesek? Az összes jelenlevők azt nyilatkozták, hogy az lehetetlenség. Ezen nyilatkozat után Kolmár József kovácsmester középtermetü erös egyén vállalkozván az átbújás megkisérlésére, levevén felsö ruháját, ing és mellényben, nagy eröfeszités után valóban átbújt a kályhalyukon és beért a szobába a nélkül, hogy a kályhán sérülést okozott volna. Eszerint a lyukon bejutás valószinütlen vállalatnak mutatkozik ugyan, nem természeti lehetetlenség. " Az épület helyiségeinek, az ott lévő tárgyaknak az állapotát részletes leírásban rögzítették. Az elhunyt áldozat ruházatával kapcsolatban kemény vizsgálóbírói intézkedés történt a szemlén. „,Feltünö lévén továbbá, hogy a meggyilkolton az eset alkalmával talált ing, kendö és ágyi lepedöje, dacára annak, hogy a nyomozó körjegyzö úr által lepecsételtetett, mégis a meghaltnak koporsójába tétetett és vele eltemettetett. Ezen ruhanemü szennyes volta a tett elkövetésére nézve felvilágositással szolgálhatván, nyomban azoknak a sír és ko- 
porsóból leendö kivétele elrendeltetett és foganatosittatott. Megjegyzendö, hogy a ruhanemükön folt, korom, piszok nem találtatott, szóval jelvény nem mutatkozott."

V. Borbála bozsoki lakos a járásbíróságnál folyó vizsgálat során tagadta, a végtárgyalás alkalmával azonban beismerte, hogy az 1875. május elsején 23 órakor szült gyermekét meggyilkolta. ${ }^{57}$ „, Kezével megfojtotta, annak hulláját 2 napig az ágyban elrejtve tartotta és az eltakaritásra alkalmasnak tartott idöben, midön a házbeliek nem voltak otthon, május 3-án reggel 2-3 óra távolságra eső szőlöben elásta. "Vallomása szerint a gyermek, álló állapotban a köldökzsinórtól szabadultan a földre esett, annyira megütötte magát, hogy midőn felvette, csak keveset élt. „Ezen állitása egészen valótlan, az orvosi boncjegyzökönyv ellenkezöjét igazolja, a hulla fején külsértésnek nyoma nem, hanem a nyakán kék vörös foltok látszottak, melyet a gége ujjával alkalmazott eröszakos nyomás következményei okozták. Hozzájárulván még a tüdö vizpróba, a szándékos gyermekgyilkosságot tüntették fel, melynek tárgyi tényálladéka a hivatkozott boncjegyzökönyvön kívül a hulla megtalálásával is, az alanyi pedig az önbeismeréssel igazolva."

A Pécsi Királyi Ügyészség által gyermeköléssel vádolt $H$. Rózsa ${ }^{58}$ cserdi lakos szintén a vizsgálat során tárta fel azt a helyet, ahol a gyermeke holttestét eltemette. „Kéthetes gyermekét avégett ásta el, hogy életétöl megfosztassék és gyermekhulla ott, ahol vádlott mutatta, feltalálva, ahol elásta."

A kihallgatások, illetve az ezek nyomán létrejött vallomások ${ }^{59}$, különösen az önvallomások (szabadvallomások), szintén fontos szerepet töltöttek be a büntetőeljárások során. A közbiztonsági közegek által végrehajtott kikérdezések tartalmát vagy jelentésekbe, jegyzőkönyvekbe foglalták, és/vagy a foganatosítókat arra vonatkozóan kihallgatták. A bizonyítás fö eszközének tartott önvallomásnak a büntett teljes vagy részleges elismerését tekintették. A kihallgatottaknak feltett kérdések általánosak és különösek. Az első kérdés tulajdonképpen egy kérdéscsokrot jelentett. Tanúk esetében a személyes adatokra vonatkozott, amelyek alapján a tanú azonosítása bármikor végrehajtható volt, továbbá törekedett tisztázni az elfogultság létét vagy nem létét. Vád-

\footnotetext{
57 MNLBaML 1875/V.451. számú irat, Pécsi Királyi Törvényszék. Az akta csak ítéletet tartalmaz, annak indokolásában került sor az idézettek kifejtésére.

58 MNLBaML 1875/V.614. számú irat, Pécsi Királyi Törvényszék. A szintén csak ítéletekből álló ügyirat egyértelműen utal arra, hogy a gyermekét megölő H. Rózsa a vizsgálat során együttműködött, és a bírói szemle idején megmutatta azt a helyet, ahol az áldozatot elásta.

59 Csoportosításukra lásd Pauler Tivadar (1873): i. m. 431-432. o.; Szlemenics Pál: i. m. 220., 225. o.
} 
lottak tekintetében szintén a személyes adatokra irányult. ${ }^{60}$ A különös kérdések a büncselekményre vonatkoztak. Az érintett ügyekben a kihallgatásokról felvett jegyzőkönyvek bemutatják a célirányos kérdésfeltevéseket, nemkülönben a gyorsaságot és a körültekintő alaposságot.

A város törvényszéke által kiküldött vizsgálóbíróság elött 1869. október 30-án tett szabadvallomásában ${ }^{61} K$. József az ,általánosakra” a következőket adta elö: „35 éves, római katolikus, pécsi születésü és illetékességü lakos, földmüves, nös, 4 gyerek apja, háztulajdonos, irni-olvasni tudok, fogva-büntetve nem voltam. ” A kihallgatásokat Doraszik Pál alügyész mint vizsgálóbíró vezette.

A K. Ferenc sérelmére elkövetett büntény kapcsán a Pécs szabad királyi város fökapitányi hivatala által 1869. november 3-án foganatosított kihallgatása során, szabadvallomásában Doraszik Pál alügyész előtt $S z$. Józsefné az „általánosakra” válaszul elmondta, hogy „,nevem Sz. Józsefné született B. Terézia, 38 éves, özvegy, kávémérö vagyok a Kigyó utcából”. A kihallgató később kérdezett rá arra, hogy volt-e már fenyítve és van-e vagyona. A jegyzőkönyvet Tobak Pál rendőri írnok és névíró ${ }^{62}$ vette fel.

B. Simon nyolcoldalas vallomása tartalmazta a következőket is:

„Szabad vallomás. Fölvéve Magyarországon 1871. évi december hó 24-én B. Simon 39 éves, római katolikus, nös, 2 gyermek atyja, mohácsi születésü és lakos, ház, föld és szölőtulajdonos a Hannover Király és Ferenc Károly sorezrednél összesen 10 és 3/4 évig szolgáltam, mint közlegény, büntetve nem,

\footnotetext{
60 „Mi a neve? Hová való születésủ és lakos? Hány éves? Micsoda vallású - állapotú - s foglalkozású egyén ön? Fogva és büntetve volt-e már? Vallomásából haszon hárul-e önre? Vallomásáért ígértetett-e valami önnek? Vádlottal ellenséges vagy rokoni viszonyban nem áll-e?" A figyelmeztetés és az első kérdés, azaz az általános kérdések a jegyzőkönyv előrenyomtatott szövegeként jelentek meg. A központi ajánlás a kérdéseket szükebben fogalmazta meg: „Neve, születési helye, kora, vallása, polgári állapota, foglalkozása, vádlotthoz viszonya, lakhelye?” A gyakorlat és a szakirodalom az elözőekben érintett bővebb kérdésfeltevést pártolta, abból kiindulva, hogy a személyt érintő kérdésekre adott válaszok alaposabban mutatják be a vallomástevőt. Az általános kérdések férfiak esetében, az 1867. szeptember 14-én kelt miniszteri rendeletnek megfelelően, kibővültek a hadkötelezettségi viszonyra vonatkozóan. A fogva tartásról és a bírósági elmarasztalásról az illetékes katonai parancsnokságot, az ítélet másolatának csatolásával, értesíteni kellett. Az 1821. szeptember 11-én kelt 23235. számú helytartótanácsi intézkedés, arról rendelkezett, hogy a vádlott életkorát anyakönyv vagy más hiteles adatok alapján szükséges kinyomozni, és a perben feltüntetni. Az 1822. április 23-án kelt 9797. számú helytartótanácsi intézkedés pedig arról, hogy a vádlott korát és egészségi állapotát, különösen fellebbviteli perben, hitelesen kimutassák, és azt, hogy a vádlott fogva volt vagy van, mióta és meddig.

61 MNLBaML 1869/V.2782. számú irat, Pécs város visszaállított törvényszéke.

$62 \mathrm{Az}$ írni-olvasni nem tudó vallomástevők X-et tettek a névíró által odaírt nevük mellé. A névíró általában a kihallgatást lefolytató, vagy a jegyzőkönyvvezető volt.
} 
megdorgálva sem voltam soha, vizsgálat alatt nem álltam, irni-olvasni nem tudok.

- Tudja-e miért van ide állitva?

- Igenis tudom, azért, mert Cs. Ivó mohácsi lakost fejszével agyonütöttem.

- Mondja el öszintén és körülményesen, hogy hol, mikor, hogyan és minö okból ütötte ön agyon Cs. Ivót?" Részletes beismerő vallomását azzal zárta, hogy „Nem akartam agyonütni, de öntudatlan lettem. Nagyon megbántam és jóvátenni szeretném."

A P. Anna négyoldalas szabadvallomásáról felvett jegyzőkönyvböl:

„Felvéve Pécsett, 1870. november 30-án aluirt (Pilch Antal) megyei esküdt által.

1. Általánosokra? P. Anna özvegyült W. Jánosné születtem Hetényen, jelenleg birjáni lakos vagyok, 25 éves, római katolikus vallású vagyok, egy 4 éves gyermek anyja vagyok, e gyermek jelenleg sógoromnál a kozári $W$. Györgynél vagyon, zárva soha nem voltam, sem büntetve más módon.

2. Tudja-e, hogy miért áll itt? Azért, mert állitólag gyermekemet, melyet $f$. év november 5-én a reggeli elsö órában szültem, meggyilkoltam volna. De ez nem igaz, mert a gyermek nem élt midön szültem. Hasmenésben szenvedtem midön kimentem éjfélkor a konyhában megszültem gyermekemet. Ez egy hangot nem adott és nem mozdult. Láttam, hogy halott, tehát betakartam keszkenömbe és kivittem az udvarba, a szalmába. Másnap reggel bátyám észrevette változásomat és faggatására elöhoztam a halott gyermeket. Ez a tény én egyebet nem mondhatok.

3. Tagadta-e bátyja elött a gyermek születését? Igen, mert féltem töle, igen csúnya volt irányomba.

4. Tehát nem sírt a gyermek? Nem.

5. Nem lélegzett? Nem.

6. Nem mozdult? Nem.

7. Nem tapasztotta be a gyermek száját? Nem. [...]

13. Azt mégis beismeri, hogy a gyermek teljesen kifejlödött volt? Igen. $[\ldots]$

20. Nem erötlenitette el nagyon a szülés, nem volt magán kívül a szülés alkalmával? Nem erötlenedtem el és magamon kívül sem voltam."

A Pilch Antal megyei esküdt, névíró által 1870. december 7-én kihallgatott $P$. József tanú előadta, hogy „Folyó év november 5-én éjjel nővérem, kinek terhes létét ismertük, 3-kor kiment a szobából és midön 4 órakor bejött, nöm észrevette rajta, hogy gyermekét megszülte. Nöm biztatására kérdöre vontam öt és hosszas tagadás és ellenkezés után egy órára rá midön ijesztet- 
tem, hogy a bíró által bekisértetem, elöhozta a gyermeket. [...] Sem hangot, sem sírást vagy egyebet nem hallottunk és csak azt emlithetem, hogy a gyermek midőn behozatott, még nem volt megmerevedve. Egyébként sem amellett, hogy élve vagy halva született volna, bizonyitékot nem tárhatok fel."

„Tekintetes nemes Baranyamegye baranyavári járásba kebelezett Németbóly községében emberöléssel vádolt A. Lörinc bünügyében 1871. évi augusztus hó 14-én fölvétetett a következö szabadvallomás.

Nevem A. Lörinc, 37 éves, római katolikus, nös, gyermektelen, szekszárdi születésü, jakabfalvi lakos vagyok, irni-olvasni tudok, vagyonom semmi sincsen.

Miért lett befogva és a biróság elé állitva? Azért fogadtattam el és állitattam a biróság elé, mert fogadó atyámat agyonütöttem.

Tehát, ha azért állittatom a biróság elé, beszélje, hogyan történt az és miért vitte véghez ezen tettet? Én most szombaton, vagyis folyó augusztus hó 12én reggel átmentem a heti vásárra Villányba, némi szükségeseket bevásárolni. S midön onnan visszajöttem fogadó apám a szobába volt, és is bementem és összeültünk az asztalhoz reggelizni. S mikor igy együtt ültünk, nékem egyszer melegedni kezdett a fejem és azon gondolat jött agyamba, hogy agyon kell ütni fogadó apámat. Ily felkészüléssel anélkül, hogy egymással szóváltásba eredtünk volna, de egymást nem is sértettük, én, mint mondám egyszerre forrongásba jöttem, hirtelen felkeltem, a szobában volt nagyfejszét felfogtam, avval elöször nyakszirt ütöttem, melynek folytán összerogyott és aztán halántékba ütöttem mindaddig még meg nem halt. [...]

Talán mégis volt valami célja, hogy ezen tettet elkövette, talán hogy fogadó atyjának vagyona végett? Az elkövetett tettemre semmi cél nem vezetett, mert fogadó atyám is szegény zsellér volt és legföljebb 100 forintja (ház) vagy valamivel több van, ezért én nem tettem, hanem mint már mondám egyszerre forróság szállta meg fejemet.

Volt-e már fogva vagy büntetve? Még soha nem voltam."

Az első intézkedést foganatosító Beck Miklós körjegyzőt 1870. augusztus 14-én hallgatta ki tanúként Bauer esküdt. Vallomását azzal zárta, hogy „Én azonnal a tekintetes szolgabiró úrhoz a hullának orvos rendörileg leendö megvizsgáltatása és a gyilkosnak biztos örizet mellett, a villányi börtönbe elkisértetése végett távsürgönyöztettem, minek folytán a tettes még aznap biztos kíséret mellett németbólyi szolgabírósághoz elkísértetett".

A cinderibogádi rablógyilkosság bünügyében elsőként intézkedő Kis Bíró József községi bírót 1873. február 22-én hallgatta Pécsett tanúként Pilch vizsgálóbíró. A tanú vallomásában megerősítette a nyomozati jegyzőkönyvben 
leírtakat és válaszolt az elhunyttal, annak a támadáskor viselt ruházatával, valamint a holttesttel kapcsolatban feltett kérdésekre.

Az elsőfokú ítélet indokolásában olvasható visszautalás az előnyomozás és a vizsgálat során felvett, majd a törvényszéken hitelesített önvallomásra. ${ }^{63}$ „M. János minden kényszer, minden reábeszélés, fenyegetés vagy bármi ígérettétel nélkül büntettét részletesen bevallotta, Vaszar község elöljárósága elött. Bevallotta továbbá Vaszaron a vizsgáló bíró előtt, végre folyó év január 13-án tartott törvényszéki ülésben, egész higgadtsággal, lelki nyugalommal, egész terjedelemben és részletesen, azon gondolat felébredésétöl kezdve, "hogy atyját, ha házasságra lép megölni«, a véres tett befejezéséig, tüzetesen, pontosan és összevágó körülményesen bevallotta."

Az előnyomozást-vizsgálatot végrehajtók foganatosították, továbbá elfogásokat, házkutatásokat, bünjelkezeléseket és más intézkedéseket is. E tevékenységek némelyike jól tetten érhetö azokban az aktákban, amelyek teljesek, de rájuk történő utalások a kisebb terjedelmú iratcsomókban is vannak. Az iratok alapján következtetni lehet arra, hogy az előállításokat, elfogásokat alapos adatgyüjtés, majd tanúkihallgatások előzték meg. A jegyzőkönyvek az utóbbiakat egyértelmüvé teszik, az előzőeket erősítik.

A K. Ferenc sérelmére a város vigalmi negyedében elkövetett büntény kapcsán szintén az 1869. november 3-án foganatosított kihallgatáson elhangzott „Miért lett elfogva és mikor? Cselédem által elkövetett verekedés végett f. é. november 2-án. ”V. Józsefet, aki Sz. Józsefné utasítására a halálos kimenetelủ verést végrehajtotta, már október 29-én, néhány tanú kikérdezése után kihallgatták. Szabadvallomásában előadta, hogy a kérdéses éjjelen Sz. Józsefné keltette fel azzal, hogy a ház előtt tartózkodókat verje meg. Amikor kiment az utcára, ott már csak egy fiatalember nézelődött, akit az udvarban felvett lécdarabbal ütött meg. A vizsgálat alaposságára utal, hogy több tanú kihallgatására került sor azért, mert felmerült a sértett munkahelyén, a fönöke által történt bántalmazása az ölés előtti időben. Ez nem igazolódott. A szomszédban tartózkodó kéjhölgyek tanúvallomásukban megerősítették, Sz. Józsefné mondta V. Józsefnek, hogy az utcán tartózkodókat üsse, ahogyan csak bírja.

E tanúk annyiban külön érdekességgel bírnak, amennyiben a védelem arra hivatkozott, hogy erkölcstelen személyek ${ }^{64}$, „Az, hogy ütésre biztattam a vádlottat 3 nyilvános kéjhölgy vallomásán alapszik, ami nem fogadható el.

63 MNLBaML 1875/V.451. számú irat, Pécsi Királyi Törvényszék. 64 Tanúk csoportosítását lásd Pauler Tivadar (1873): i. m. 438. o. 
1486. évi 14. tc. 5. \$-a úgy 1613. 23. tc. 16. \$-a nyiltan eltiltja az erkölcstelen személyt a tanúskodástól, amiböl következik, hogy nekik hitelt nem szabad a biróságnak adni." A bíróság nem fogadta el a védői érvelést.

A tényállás szerint $F$. József ${ }^{65} 1870$. szeptember 4-én a szőlőben elrejtett puskáját magához véve Becefa körül bolyongott azért, hogy $D$. Julist megláthassa, és gyilkolási szándékát rajta véghezvihesse. „Aznap este D. Julis elment a falu fölött fekvö mészárszékbe húsért. Amikor visszafelé jött a pincéknél elöugrott F. József és 15-20 lépésnyi távolságból hasba lötte. Meghalt a lövés következtében. F. József elszaladt, néhány napig kóborolt, míg szeptember 6-án Pécsett a városi hajdúk által elfogatott. [...] A lövés után elrejtözött, majd atyjával találkozva, annak elmondta tettét és, hogy magát is ki akarja végezni."

A cinderibogádi rablógyilkosság ügyében Pilch vizsgálóbíró 1873. február 26-án több intézkedést foganatosított az elrabolt tárgyak felkutatására és biztosítására.

Beke Antal megyei pandúr káplárt bízta meg azzal, hogy D. Péterrel menjen Tengerinbe, és foglalja le az ott elrejtett pénzt. A falu bírója igazolta, hogy a meghozott 257 forint bankópénzt D. Péter nagybátyja fészerében, a gyékény alatt találták fel, egy cekkerben. D. Péter elismerte, hogy a felkutatott összeg a rablógyilkosság során elvett pénzből rá eső jutalék.

A bizonyítvány egyik oldalára ceruzával rájegyezve „,tengerini D. Péternél van egy cekkerli és 200 forint, amit a gyilkoláskor elraboltak".

Ezután a vizsgálóbíró, Beke Antal káplár, Szabadi József molnármester, szabadi lakos és Berenkó József mindszenti bíró jelenlétében $D$. József mindszenti házához ment, ahol annak nejét felszólította a férje által neki adott pénz kiadására. Az asszony hosszas keresés és tettetett együgyüséggel az almáriumon fekvő ruhanemü között feltalált egy kendőbe kötve 190 forintot, mely pénzösszeg lefoglalásra került.

Ezt követően elmentek I. János házához, ahol annak atyja jelenlétében szorgosan átkutatták az istállóban a tettes által megjelölt helyet, de a pénzt nem találták meg. Ezért I. Jánost az istállóba bevezették, akinek egyszerü kijelentésére a 340 forintot egy kis barna pénztárcában feltalálták és bírói kézhez vették.

A lefoglalt pénzen felül az egyéb nyomozati cselekmények során felkutatott értékek bírói letétbe vétele is megtörtént. Közéjük tartozott a 787 forint készpénz, valamint egy agyagfazékban talált, zömmel ezüstérmékből álló

65 MNLBaML 1872/V.7. számú irat, Pécsi Királyi Törvényszék. 
848 forint 20 krajcár. A törvényszék az értékeket a Pécsi Magyar Királyi Adóhivatalnál letétbe helyezte és a keletkezett okmányokat az elő iratokhoz csatolni rendelte. ${ }^{66}$

Z. Mihály ${ }^{67}$ pécsi lakos 1874. július 30-án 12.30-kor egy nagy és élesre köszörült konyhakéssel felfegyverkezve $d r$. $S$. Károly lakására olyan elhatározott szándékkal ment, hogy ôt bosszúból meggyilkolja. Z. Mihály a gyilkosság végrehajtási szándékával akkor hagyott fel, midőn S. Károly a kést megfogta és pénzt ígért, majd húsz forintot adott, amellyel azután eltávozott. Az elkövetés után, rövid idő elteltével, a városi rendőrök elfogták, az átvett húsz forintot hiánytalanul megtalálták és le is foglalták. Z. Mihályt azonnal letartóztatták, majd a vizsgálóbíró vizsgálati fogságba helyezte.

F. Maxim 1870. november 5-én M. Jánost egy vermelö kapával agyonütötte, holttestét a szántóföldre hurcolta, és ott tökkel és gazzal letakarta. Tettét csak akkor vallotta be, midőn gazdája hulláját meglátta. ${ }^{68}$

\section{Zárógondolatok}

Kellően kitapintható, hogy a közbiztonsági feladatokat végrehajtó testületek, illetve személyek létszáma, felszerelése és eszközei erőteljesen függtek a rájuk fordítható anyagi javaktól. Megjegyzendő ugyanakkor, hogy a felelősségre vont elkövetőkkel a felmerült kiadásokat megfizettették, de legalábbis törekedtek megfizettetni.

A Pécs-Baranyában folytatott eredményes bünüldöző tevékenység, annak ellenére, hogy történtek súlyos büncselekmények ${ }^{69}$, a közállapotokra is kedvező hatást gyakorolt.

Jóllehet a kérdéses időszakban még épp csak fel-feltünedeztek a kriminalisztika csírái, a vizsgált ügyek aktái olyan szaktudásról ${ }^{70}$ tesznek tanúbizonyságot, amellyel a nyomozástan tudománnyá válása után sem vallottak volna szégyent a rendőri és a vizsgálóbírói apparátus tagjai. A rendőri tevékenysé-

\footnotetext{
66 A bírói letétek kezelése tárgyában a magyar királyi igazságügy miniszternek 1872. január 2-án kelt 13295/1871. sz. alatt kiadott rendelete alapján a bírói letétek a királyi adóhivatalokban őrzendők. 67 MNLBaML 1874/V.876. számú irat, Pécsi Királyi Törvényszék. 68 MNLBaML 1872/V.319. számú irat, Pécsi Királyi Törvényszék.

69 További például postakocsirablás, amelynek az elkövetőit felderítették, őket gyilkosság és rablási kísérlet miatt elítélték. MNLBaML 1873/V.398.

70 Visszautalás B. Simon emberölésére és P. Anna gyermekölésére, továbbá megjegyezve, hogy a kihallgatások során nem egy vádlottnak, illetve tanúnak kellett több mint hatvan, jegyzőkönyvileg rögzített, a releváns körülményekre vonatkozó kérdésre válaszolnia.
} 
get ellátó közbiztonsági tisztviselők és közbiztonsági közegek, az 1869 és 1872 közötti években született törvényi előírások bevezetésekor megmutatkozó átmeneti nehézségek ellenére a feladataikat igyekeztek a legjobb tudásuk szerint végrehajtani.

Pécs szabad királyi városban 1870-ben kétszázhetvenhárom feljelentés érkezett a törvényszékhez. Befejeződött kétszázhét ügy. Fogva volt százhetvennégy személy. Emberölés miatt perbe fogtak tíz embert, közülük elítéltek öt férfit és két nőt. Egy és öt év közötti szabadságvesztésre négy, egy év alattira három embert. Emberölés vétkes vigyázatlanság miatt egy év alatti szabadságvesztésre ítéltek két férfit. ${ }^{71}$

A cinderibogádi rablógyilkosságban a vizsgálóbírót erőteljesen foglalkoztatta az elhunyt életvitele, gazdagsága; a behatolás helye; az elvitt dolgok; az időjárási viszonyok; a környékbeli korábbi büncselekmények; az adósok kiléte, tartozásuk nagysága; S. József szomszéd távolléte; a környéken ismert bünelkövetők. Nyomozása irányának helyessége be is igazolódott.

Kassay az általános vizsgálatra vonatkozóan kifejtette, hogy megkezdéséhez büntény gyanúja szükséges. A vizsgálatot végzőnek meg kellett győződnie a büntény elkövetésének valóságáról, a bünösről és a büntény körülményeiről. Ehhez kellett, hogy az elkövetett büntett helyén fennmaradt nyomokat vizsgálja meg; gyilkosságnál a test felbontása által magának kellő tudomást szerezzen; az elkövetés eszközeit őrizet alá tegye. Továbbá a sértett, a hozzátartozók, a szomszédok - mint a büntényről tudomással bírni vélő egyének - vallomását vegye ki, a távoli jegyekről tudomással bírókat tanúként hallgassa ki, ha indokolt, tartson házkutatást. A különös vizsgálatnak helye volt beismerő önvallomás, tettenérés, hites tanúk vallomásai esetén, illetve alapján. ${ }^{72}$

71 MNLBaML 1871/V.249.

72 Kassay Adolf: i. m. 87-88. o. 